\title{
LSEResearch Online
}

\section{- -}

\section{John Ryan}

\section{The European Central Bank, Italy and the next Eurozone crisis}

\section{Article (Accepted version) (Refereed)}

\author{
Original citation: \\ Ryan, John (2018) The European Central Bank, Italy and the next Eurozone crisis. The \\ Economists' Voice. ISSN 1553-3832
}

DOI: https://doi.org/10.1515/ev-2018-0022

(C) 2018 Walter de Gruyter GmbH, Berlin/Boston

This version available at: http://eprints.Ise.ac.uk/id/eprint/91314

Available in LSE Research Online: December 2018

LSE has developed LSE Research Online so that users may access research output of the School. Copyright (c) and Moral Rights for the papers on this site are retained by the individual authors and/or other copyright owners. Users may download and/or print one copy of any article(s) in LSE Research Online to facilitate their private study or for non-commercial research. You may not engage in further distribution of the material or use it for any profit-making activities or any commercial gain. You may freely distribute the URL (http://eprints.Ise.ac.uk) of the LSE Research Online website.

This document is the author's final accepted version of the journal article. There may be differences between this version and the published version. You are advised to consult the publisher's version if you wish to cite from it. 
John Ryan ${ }^{1,2, a}$

\title{
The European Central Bank, Italy and the Next Eurozone Crisis
}

\author{
${ }^{1}$ London School of Economics and Political Science, IDEAS, London SW15 6SS, United Kingdom of Great Britain and Northern \\ Ireland, E-mail: J.T.Ryan@lse.ac.uk \\ ${ }^{2}$ Brexit Partners, Flat 7, 307 Upper Richmond Road London SW15 6SS, United Kingdom of Great Britain and Northern Ireland, \\ E-mail: J.T.Ryan@lse.ac.uk
}

\begin{abstract}
:
The European Central Bank (ECB) is the least accountable central bank among advanced nations. Its degree of independence has only one precedence: the German Reichsbank, a central bank with one of history's most disastrous records. The lessons of German history do not seem to be interpreted correctly by the ECB.
\end{abstract}

Keywords: Bundesbank, European Central Bank, Eurozone

DOI: $10.1515 /$ ev-2018-0022

\section{Italy is Too Big to Fail and may be Too Big to Save}

If one country does poorly, blame the country; if many countries are doing poorly, blame the system. As Joseph Stiglitz put it in his book "The Euro: How a Common Currency Threatens the Future of Europe", the Euro was a system almost designed to fail. ${ }^{1}$ The European Central Bank (ECB) has been piling up bad debt on its balance sheet and it just extends the maturity time for the bonds. For example, Greek bonds held by the ECB are way past their original due date. But the ECB has just extended maturity about 40 years or so. They also reduce the interest rate on these bonds. The Greek debt is held on the ECB balance sheet at par value when its present value is near zero. Is this what will happen to the Italian debt in the future? ${ }^{2}$

How to manage sovereign debt emergencies is turning into a major battle line over Eurozone reform. Two camps of countries hold what appear to be diametrically opposed positions. Unless they find a compromise, a much-awaited initiative on strengthening the Eurozone's defences is unlikely to go far enough to remove doubts about its vulnerability in future crises.

On one side stands a German-led group of countries, which insists that emergency bailouts must go hand in hand with debt restructurings that impose losses on private holders of government bonds. On the other side stands a French-led group of countries which contends that mandatory debt restructurings would inject turmoil into financial markets, risk the Eurozone's break-up and fuel anti-EU political extremism.

Arguably, Italy is even more nervous than France about the German-inspired proposals. This is hardly surprising, given that Italy's public debt amounts to a colossal $€ 2.3 \mathrm{tn}$ - representing about 132 per cent of annual economic output. For Italy any proposal to force losses on private owners of Rome's sovereign debt could wreak havoc in the banking system by highlighting the "doom loop" between an over-indebted government and overexposed banks.

In this context, it is important to understand that Italy is not Greece. The Italian economy is 10-times bigger. Its $€ 2.3$ tn public debt is seven-times bigger; it has the largest debt in the Eurozone and fourth largest in the world. Italy is too big to fail and may be too big to save.

\section{Is the ECB Fit for Purpose?}

The ECB needs to be looked at in the context of its past record. It has strayed from its mandate into economic and fiscal policy. The ECB was supposed to be like the Bundesbank. While the ECB can justly claim to have held together a poorly-designed system in difficult circumstances, ${ }^{3}$ the mission creep is its own responsibility.

Not only is the ECB shielded from politicians, the ECB's statutes have also placed it beyond the reach of democratic rules that sanction bad behaviour. The ultimate control which politicians have over a central bank 
lies in the fact that they can change its statutes: the terms of appointment for governors, for example. This was the case in Germany, where a simple majority in parliament could change Bundesbank law. But this possibility is totally absent in the Eurozone. The statutes of the ECB can only be changed by revising the Maastricht Treaty, which requires unanimity of all member countries. ${ }^{4}$

On paper, the ECB enjoys full independence. Its board members cannot be revoked and their long eightyear mandate cannot be renewed, so that they do not have to please member governments. The ECB Governing Council can at any time, with a majority vote, decide the fate of at least half a dozen governments, supporting them or bringing them down - and that number is increasing. It is therefore important that the ECB is placed under a stricter and more direct supervision by democratically elected politicians.

The independence of central banks was initially granted in order to enable them to provide their core product - monetary stability. The ECB today argues that the only institution that has the right to limit its power is the European Court of Justice, which has an activist Europhile interpretation of European treaties.

The ECB is the least accountable central bank among advanced nations. Its degree of independence has only one precedence: the German Reichsbank, a central bank with one of history's most disastrous records. The lessons of German history do not seem to be interpreted correctly as the ECB was created on the wrong foundations. Instead of adopting those features that made the Bundesbank successful - accountability and interdependence with other democratic institutions - the creators of the ECB revived the corpse of the unaccountable Reichsbank. ${ }^{5}$

\section{Draghi's Conundrum}

In 2015, Mario Draghi, president of the ECB, decided to extend Euro-QE into March 2017. Then, he extended Euro-QE to December 2017, with a promise to do more if necessary. There was taper talk in the ECB's QE programme in 2017. In October 2017, the ECB announced, that starting in January 2018, its asset purchases would followed a monthly purchase of $€ 30$ billion until the end of September 2018. The ECB then intends to halve its monthly purchases of bonds to €15bn between October 2018 and December 2018 and will stop them at the end of 2018, and sees no prospect of an increase in the ECB's key lending rate - currently $0.0 \%$ - until the summer of 2019 at the earliest. But what would that mean for the countries, companies, and banks that have grown to depend so much on the ECB?

Meanwhile, the European interest rate cycle is turning. The days of low interest rates are not quite over yet, but borrowing costs look set to start rising. Interest rates have remained lower for longer than we might have expected, but it is good to remember that a zero base rate and a central bank pumping money into the economy through purchasing bonds is not the norm.

The main reason those bonds bear negative yields is Draghi's massive multi-year bond buying. The dreaded "Doom Loop" - when shaky banks hold too much shaky government debt, raising the fear of contagion across the financial system if one of them stumbles - is still very much alive in Italy despite Mario Draghi's best efforts to transfer ownership of Italian debt from banks to the ECB.

ECB policy-making has become less accountable, and more controversial and politicized. At the very least, the reinforcement of democratic scrutiny over ECB policy making is more urgent than ever. The evidence points to the ECB as both a technocratic and a political Leviathan within the Eurozone. ${ }^{6}$

\section{Notes}

1 Joseph E. Stiglitz, "The Euro: How a Common Currency Threatens the Future of Europe", Allen Lane Publishers, 2016

2 Martin Sandbu, Europe's Orphan: The Future of the Euro and the Politics of Debt (Princeton University Press, 2015).

3 Harold James, Making the European Monetary Union (Harvard University Press, 2014).

4 Paul De Grauwe, "ECB is a Law unto Itself," Financial Times, 12 Nov. 1998.

5 Richard A. Werner, "A Comparative Analysis of the Independence of the ECB, the Bundesbank and the Reichsbank," International Finance Review, 6, (2006), 1-16.

6 Paul Tucker, Unelected Power: The Quest for Legitimacy in Central Banking and the Regulatory State (Princeton University Press, 2018).

\section{References}

de Grauwe, Paul. 1998. "ECB is a Law unto Itself." Financial Times, 12 November.

James, Harold. 2014. Making the European Monetary Union. Cambridge, MA: Harvard University Press.

Sandbu, Martin. 2015. Europe's Orphan: The Future of the Euro and the Politics of Debt. Princeton, New Jersey: Princeton University Press. 
Stiglitz, Joseph E. 2016. The Euro: How a Common Currency Threatens the Future of Europe. Allen Lane Publishers.

Tucker, Paul. 2018. Unelected Power: The Quest for Legitimacy in Central Banking and the Regulatory State. Princeton, New Jersey: Princeton University Press.

Werner, Richard A. 2006. "A Comparative Analysis of the Independence of the ECB, the Bundesbank and the Reichsbank." International Finance Review 6: 1-16. 